\title{
Arthroderma otae
}

National Cancer Institute

\section{Source}

National Cancer Institute. Arthroderma otae. NCI Thesaurus. Code C127685.

A species of zoophilic dermatophyte fungi in the phylum Ascomycota. This species

causes superficial infections of the scalp (tinea capitis) in humans. 